\title{
La Universidad de Granada divulga la práctica trashumante desde la vivencia
}

Con el curso Trashumancia: Los caminos del pastoreo itinerante. Conocimiento práctico de un patrimonio cultural, celebrado a principios de junio, los estudiantes de la Universidad de Granada han tenido la ocasión de conocer de cerca la práctica trashumante. Organizado por el Centro Mediterráneo, convalidable por 6 créditos ECTS, un grupo de 12 estudiantes acompañaron durante cinco jornadas al rebaño de los hermanos Pérez, pernoctando en el campo y ayudando en todas las faenas propias de esta actividad.

Ángel Acuña Delgado | catedrático del Dpto. de Antropología Social de la UGR, director del curso

URL de la contribución <http://www.iaph.es/revistaph/index.php/revistaph/article/view/4401>

La trashumancia constituye uno de los dos grandes patrones de movimiento que produce el pastoreo (además del nomadismo). Movimiento anual de ida y vuelta en donde el ganado es conducido hacia las zonas altas buscando los pastos de primavera y verano (agostada), y hacia las zonas bajas en busca de los de otoño e invierno (invernada). Sistema ganadero extensivo, integrado en el medio natural, que conforma un espacio característico de vías pecuarias (cañadas, veredas, cordeles) los cuales discurren por paisajes de gran valor ecológico.

Los pastores trashumantes, personas que se mueven al ritmo de las estaciones, entregados al cuidado de sus animales, revelan un profundo conocimiento del territorio que pisan y un enorme acervo cultural heredado de sus antepasados, y basado en un modo de vida cíclico que lo ligan al mundo rural. En el presente, no obstante, enfrentan serias dificultades económicas y administrativas para seguir con su actividad.

El curso que presentamos, que constituye una continuación de las tres ediciones ya realizadas entre 2010 y 2012, pretendió acercar a sus participantes una manifestación de nuestro patrimonio cultural, en otro tiempo más extendido, poner en valor el esforzado trabajo que realizan los pastores, y vivir junto a ellos una experiencia inolvidable, por bellos parajes. Así, en compañía de los pastores, los hermanos Pérez, Pedro y Tomás, realizamos un recorrido primaveral por las "vereas" de Sierra

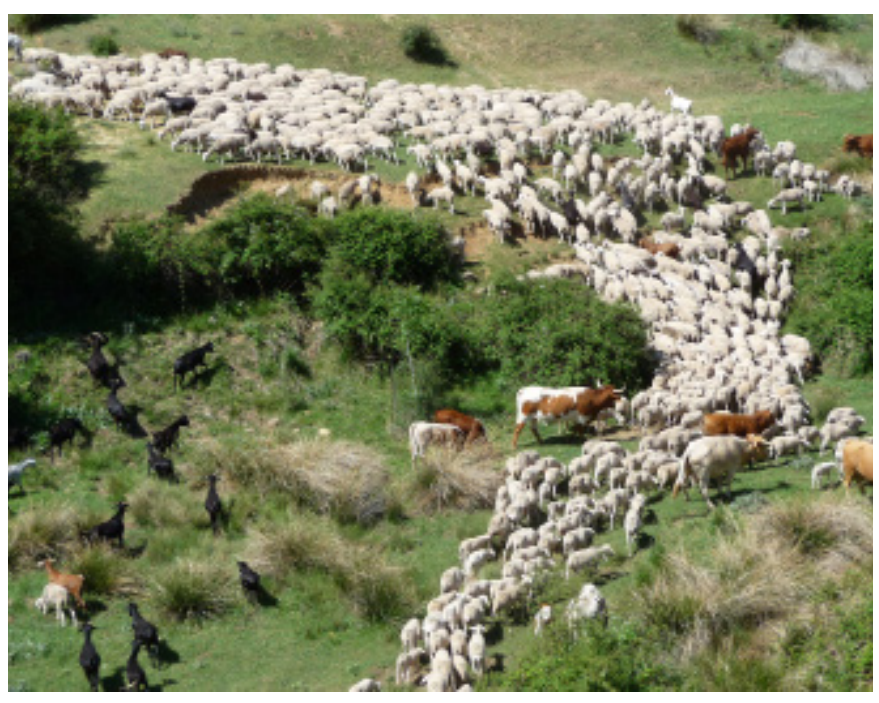

Vereda trashumante que va desde Linares hasta Pontones | foto Ángel Acuña, Delgado, autor de todas las imágenes que ilustran esta contribución

Morena y Sierra de Segura, en la provincia de Jaén, que nos reveló las razones antropológicas y ecológicas por las que es importante que esta práctica no se pierda.

El curso contó con una base teórica en aula pero tuvo una orientación eminentemente práctica. El alumnado participante tuvo ocasión de aprender cuál ha sido la historia y cuál es el estado actual en que se encuentra la práctica trashumante y las vías pecuarias en España, la problemática económica, social y jurídico-administrativa que la envuelve; cómo se está llevando a cabo la recuperación y qué nuevos usos recreativo-deportivos se le 


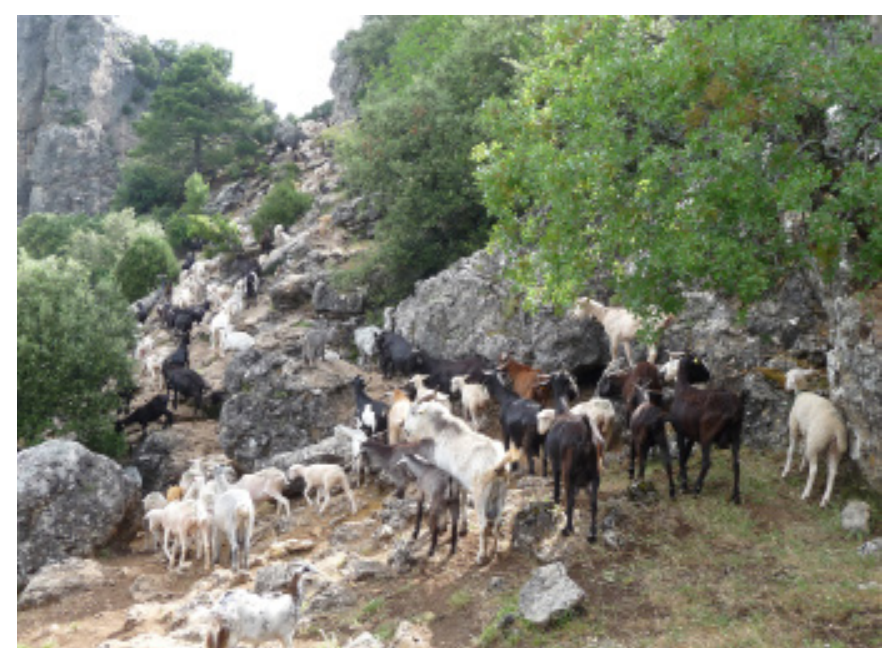

Vereda trashumante que va desde Linares hasta Pontones

están dando a dichas vías. Asimismo, todo lo relacionado con la cultura trashumante fue llevado a cabo desde el conocimiento práctico producido sobre el terreno, acompañando al ganado, comiendo y durmiendo junto a los rebaños, participando de las veladas nocturnas, todo ello de la mano y con la experiencia de quienes mejor la pueden mostrar y transmitir: los propios pastores.

La puesta en valor de esta tradicional actividad a partir del conocimiento ciudadano constituye un elemento clave para que cobre prestigio social y apoyo político. La Universidad, como institución productora de conocimiento, puede colaborar, en este caso con el reconocimiento, recuperación y difusión del papel desempeñado por la trashumancia y los pastores; ampliando el espacio académico fuera de las aulas sin rigideces de límites horarios. Pero más allá del saber adquirido, la experiencia práctica del alumnado permitió estimular los sentidos y tal vez despertar cierta sensibilidad oculta, porque, ¿cómo describir o reaccionar ante la sensación de verse envuelto por los sonidos de cencerros multitonales, acompañados por el valar y mugir de los animales que envuelve el ambiente a modo de perfecta sinfonía? ¿Qué sentir de nuestra propia naturaleza animal al introducirnos en marcha dentro de la manada? ¿Cómo entender la conexión entre el pastor y su rebaño, la respuesta esperada que producen las ovejas al silbido o al grito seco y contundente de quien las guía? ¿Qué decir de los amigos pastores, que de manera desinteresada y

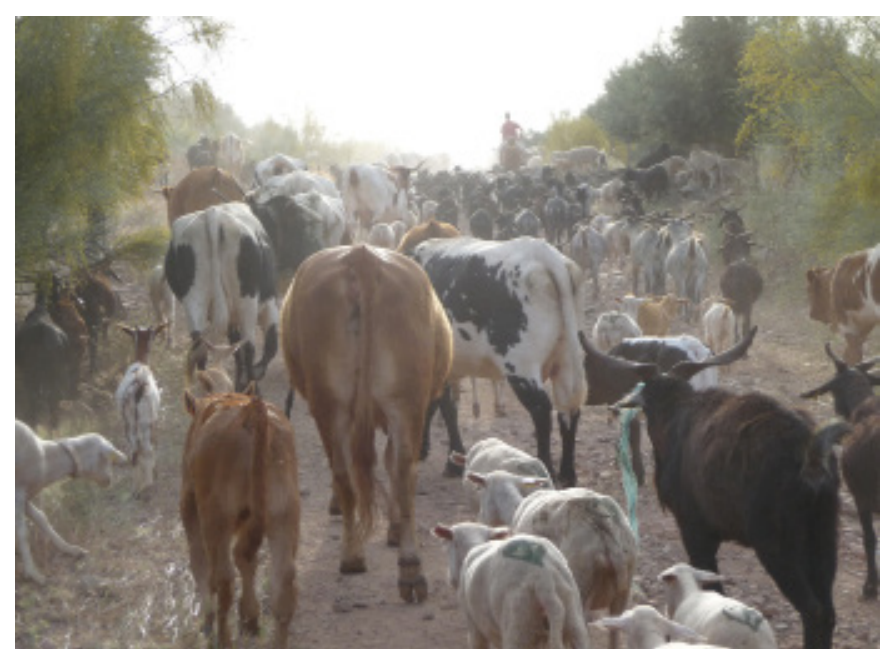

solidaria ayudan en parte o en la totalidad del recorrido a los hermanos Pérez, propietarios de la ganadería en movimiento?

En la sociedad del conocimiento que decimos estar instalados, no hay que perder de vista que lo que somos se lo debemos a nuestros pasados, y que la gran riqueza de nuestra especie reside en la diversidad de formas que tenemos para afrontar la vida. Ignorar la realidad trashumante no es propio de una sociedad del conocimiento. Falta más atención estatal y reconocimiento social sobre el sacrificado trabajo de quienes mantienen un patrimonio cultural repleto de sentido ecológico y solidario. $Y$ es preciso al menos visibilizar una ocupación vocacional junto a sus protagonistas, que desde el silencio ofrecen permanentes lecciones de saber estar en la naturaleza, y que por su perseverancia en seguir siendo quienes son, reconocemos y admiramos como uno de los últimos románticos. 